\title{
MANAJEMEN STRATEGISPERUSAHAAN
}

Makalah ini disusun guna memenuhi tugas mata kuliah

"PENGANTAR MANAJEMEN"

Dosen Pembimbing :

Dra. Hj. Nuraeni Gani.M.M

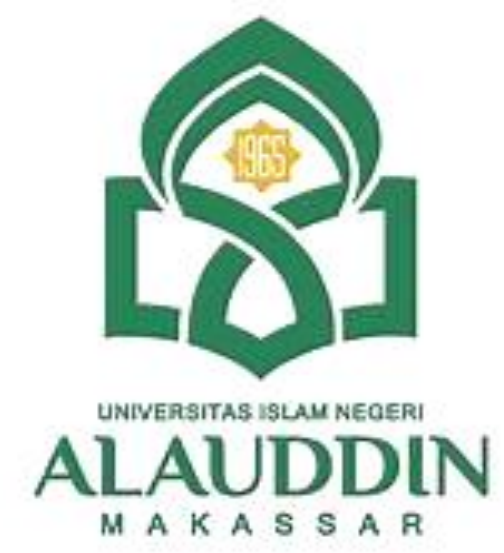

DISUSUN OLEH :

NURUL UYUN

90500121016

PRODI PERBANKAN SYARIAH

FAKULTAS EKONOMI DAN BISNIS ISLAM

UNIVERSITAS ISLAM NEGERI MAKASSAR

2021 M / 1443 


\section{KATA PENGANTAR}

Alhamdulillah, segala puja dan puji syukur kehadirat Allah swt. Yang telah memberikan kami kesehatan serta kesempatan sehingga kami bisa mengerjakan serta menyelesaikan makalah ini.

Shalawat serta salam semoga selalu terlimpah kepada Rasulullah Muhammad saw. yang telah menyampaikan risalah wahyu sebagai petunjuk untuk meraih kebahagiaan di dunia dan akhirat kelak.

Selanjutnya, terima kasih kami ucapkan kepada Ibu Dra. Hj. Nuraeni Gani.M.M

selaku dosen pembimbing mata kuliah "PENGANTAR MANAJEMEN" ini, atas bimbingannya. Alhamdulillah kami dapat menyelesaikan makalah ini meskipun masih banyak terdapat kekurangan di dalamnya. Karena itu, kritik dan saran sangat kami harapkan dalam upaya penyempurnaan makalah ini. Akhirnya, semoga makalah ini dapat memberi manfaat kepada kita semua. Amin.

Makassar, September 2021

Pemakalah 


\section{DAFTAR ISI}

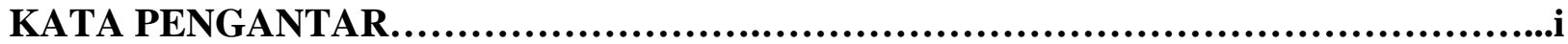

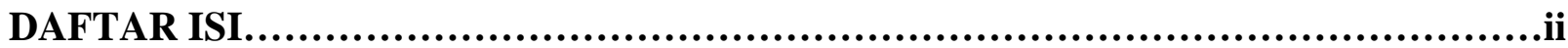

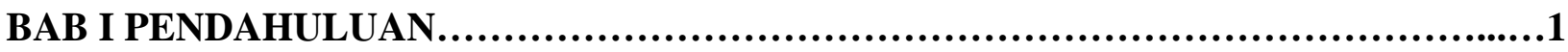

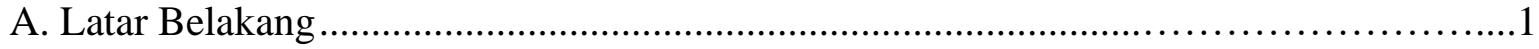

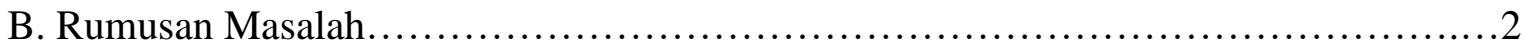

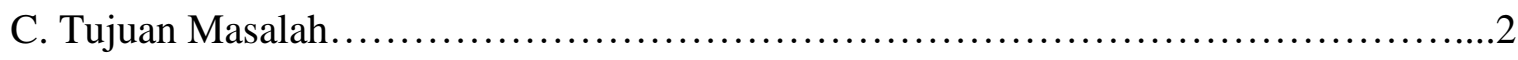

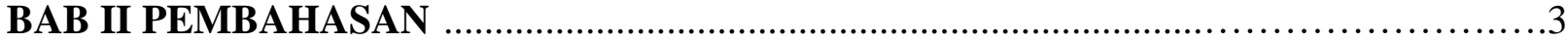

A. Konsep dasar manajemen strategis .................................................

B. Melakukan manajemen strategis .....................................................

C. Tingkatan-tingkatan Manajemen Strategis.......................................

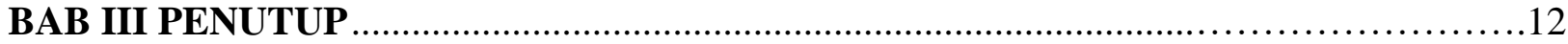

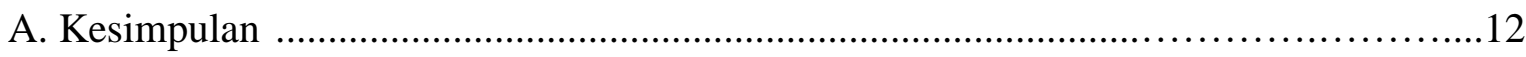

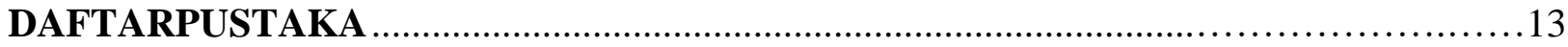




\section{BAB I}

\section{PENDAHULUAN}

\section{A. Latar Belakang}

Manajemen strategis adalah seni dan ilmu penyusunan, penerapan, dan pengevaluasian keputusan-keputusan lintas fungsional yang dapat memungkinkan suatu perusahaan mencapat sasarannya. Manajemen strategis adalah proses penetapan tujuan organisasi, pengembangan kebijakan dan perencanaan untuk mencapai sasaran tersebut, serta mengalokasikan sumber daya untuk menerapkan kebijakan dan merencanakan pencapaian tujuan organisasi. Manajemen strategis mengkombinasikan aktivitas-aktivitas dari berbagai bagian fungsional suatu bisnis untuk mencapai tujuan organisasi.

Manajemen strategis berbicara tentang gambaran besar.Inti dari manajemen strategis adalah mengidentifikasi tujuan organisasi, sumber dayanya, dan bagaimana sumber daya yang ada tersebut dapat digunakan secara paling efektif untuk memenuhi tujuan strategis.Manajemen strategis di saat ini harus memberikan fondasi dasar atau pedoman untuk pengambilan keputusan dalam organisasi. Ini adalah proses yang berkesinambungan dan terus-menerus.

Menurut Thomas L.Wheelen - J. David Hunger manajemen strategi adalah serangkaian dari pada keputusan majerial dan kegiatan-kegiatan yang menentukan keberhasilan perusahaan dalam jangka panjang. Kegiatan tersebut terdiri dari perumusan / perencanaan strategi, pelaksanaan / implementasi, dan evaluasi lingkungan dunia yang mengalami perubahan seperti adanya globalisasi, control masyarakat, perkembangan teknologi, memberikan dampak bagi perkembangan suatu negara maupun bisnis. Control masyarakat terhadap pelaksanaan kegiatan pemerintahan maupun perusahaan, sehingga pemerintah maupun pemimpin perusahaan tidak dapat membuat kebijakan yang mengabaikan kepentingan masyarakat. Oleh sebab itu dalam menjalankan kegiatannya perlu adanya keselarasan antara kompetensi yang dimiliki perusahaan maupun pemerintah dengan lingkungan yang ada di luar organisasi (perusahaan dan pemerintah).

Pertimbangan global praktis berdampak pada keputusan strategis, batas-batas negara diabaikan.Untuk mengetahui dan menghargai dunia dari perspektif orang lain telah menjadi masalah hidup atau mati untuk bisnis. Dengan demikian perlu adanya kegiatan dalam pengambilan keputusan yang disesuaikan antara kemampuan yang dimiliki dengan lingkungan yang ada di sekitar sehingga perlunya adanya manajemen strategi.Menopang manajemen strategis tergantung pada manajer mendapat pengertian mengenai pesaing, pasar, harga, pemasok, distributor, pemerintah, kreditor, pemegang saham dan pelanggan diseluruh dunia. Harga dan mutu dari produk dan jasa perusahaan harus dapat bersaing di seluruh dunia, bukan hanya di pasar lokal.

Persaingan yang memunculkan daya saing erat kaitannya dengan pemahaman mekanisme pasar (standar dan benchmarking), kecepatan dan ketepatan penyampaian produk (barang dan jasa) yang mampu menciptakan nilai tambah.Oleh karena itu, peningkatan daya saing organisasi bersifat unik, tetapi pada intinya dipengaruhi oleh aspek kreativitas, kapasitas, teknologi yang diguna-kan dan jangkauan pemasaran yang dicapai.Hal tersebut diwujudkan dari tampilan produk, produktivitas yang tinggi dan pelayanan yang baik. 


\section{B. Rumusan Masalah}

Oleh karena masalah yang dikemukakan di atas terlalu luas dan supaya tidak menyimpang dari materi maka penyusun merumuskan beberapa masalah sebagai berikut :

1. Apa pengertian manajemen strategi ?

2. Apa saja komponen strategi?

3. Bagaimana cara melakukan penyusunan Manajemen Strategi?

4. Bagaimana proses dari Manajemen Strategi?

5. Apa saja tingkatan strategi untuk perusahaan?

\section{Tujuan Makalah}

Tujuan penulisan ini adalah sebagai berikut :

1. Memenuhi tugas mata kuliah Manajemen Perusahaan.

2. Menjelaskan pengertian manajemen strategis

3. Menguraikan komponen strategi.

4. Menjelaskancara melakukan penyusunan Manajemen Strategi?

5. Menjelaskan proses dari Manajemen Strategi?

6. Menyebutkan dan menelaah tingkatan strategi untuk perusahaan? 


\section{BAB II \\ PEMBAHASAN}

\section{A. KONSEP DASAR MANAJEMEN STRATEGIS}

Bab sebelumnya telah menjelaskan pentingnya fungsi perencanaan dalam manajemen organisasi perusahaan. Salah satu jenis perencanaan yang telah diuraikan dalam bagian sebelumnya adalah perencanaan jangka panjang atau strategic planning. Perencanaan ini dimaksudkan bukan sekadar untuk mencapai tujuan perusahaan dalam jangka panjang. akan tetapi juga untuk memastikan bahwa perusahaan dapat bertahan dalam jangka panjang Topik yang membahas mengenai cara bagaimana perusahaan dapat memelihara keberlangsungan operasinya dalam jangka panjang, yaitu manajemen strategis (strategi management) Apa yang dimaksud dengan manajemen strategis? Sebelum menjawab pertanyaan ini tentunya perlu kita pahami setiap istilah yang tercakup dalam manajemen strategis, khususnya istilah strategis.

\section{Pengertian Strategi}

Griffin (2000) mendefinisikan strategi sebagai rencana komprehensif untuk men capai tujuan organisasi. (Strategy is a comprehensive plan for accomplishing an organization's goals) Tidak hanya sekadar mencapai, akan tetapi strategi juga dimaksudkan untuk mempertahankan keberlangsungan organisasi di lingkungan di mana organisasi tersebut menjalankan aktivitasnya. Bagi organisasi bisnis, strategi dimaksudkan untuk mempertahankan keberlangsungan bisnis perusahaan dibandingkan para pesaingnya dalam memenuhi kebutuhan konsumen.

\section{Komponen Strategi}

Secara umum, sebuah strategi memiliki komponen-komponen strategi yang senantiasa dipertimbangkan dalam menentukan strategi yang akan dilaksanakan. Ketiga komponen tersebut adalah:

a. Kompetensi yang berbeda, adalah sesuatu yang dimiliki oleh perusahaan di mana perusahaan melakukannya dengan baik dibandingkan dengan perusahaan lainnya. Dalam pengertian lain, kompetensi yang berbeda bermakna kelebihan perusahaan dibandingkan perusahaan lainnya. Pemasaran dan pembayaran secara online adalah salah satu kompetensi yang berbeda yang dimiliki oleh Amazon.com jika dibandingkan dengan penjual buku secara manual melalui gedung atau toko-toko penjualan Kom petensi yang berbeda ini akan menjadi kekuatan bagi strategi yang akan dijalankan oleh perusahaan. 
b. Ruang lingkup, adalah lingkungan di mana organisasi atau perusahaan tersebut ber aktivitas. Lokal, regional, atau internasional adalah salah satu contoh ruang lingkup dari kegiatan organisasi. Oleh karenanya, strategi yang akan dilakukan mencakup ruang lingkup yang dihadapi oleh perusahaan.

c. Distribusi sumber daya, adalah bagaimana sebuah perusahaan memanfaatkan dan mendistribusikan sumber daya yang dimilikinya dalam menerapkan strategi perusa haan. Sebagai contoh, perusahaan raksasa General Electric memanfaatkan profit yang diperolehnya dari Amerika untuk diinvestasikan di Asia dan Eropa sebagai strategi ekspansi yang dilakukannya.

\section{Jenis Strategi}

Menurut Griffin(2000), secara umum strategi dapat dibagi menjadi dua jenis dilihat dari tingkatannya. Pertama adalah strategi pada tingkat perusahaan (corporate-level strategy) Kedua, strategi pada tingkat bisnis (business level strategy) Strategi pada level perusahaan atau korporat dilakukan perusahaan sehubungan dengan persaingan antarperusahaan dalam sektor bisnis yang dijalankannya secara keseluruhan. Persaingan yang ditunjuk kan melalui Mie Sedap dan Supermie Rasa Sedap, pada level perusahaan sesungguhnya menunjukkan persaingan antara kelompok perusahaan Indofood dan Wings Food, yaitu persaingan pada bisnis makanan. Strategi pada level bisnis adalah alternatif strategi yang dilakukan oleh perusahaan sehubungan dengan persaingan bisnis yang dijalankannya pada beberapa jenis bisnis yang diperdagangkan. Persaingan antara Mie Sedap dan Supermie Rasa Sedap pada dasarnya menunjukkan strategi pada tingkat bisnis, yaitu dalam bisnis mie instan. Berbeda dengan Griffin, Stoner, Freeman, dan Gilbert (1995) menambahkan kedua jenis strategi tadi dengan tingkatan strategi ketiga, yaitu strategi pada tingkat fungsional functional level strategy). Iklan yang berganti ganti pada produk Sunsilk dan Pantene (yang seolah-olah saling berbalasan satu sama lain) menunjukkan strategi pada tingkat fungsional, di mana kedua perusahaan melakukan strategi pada bagian pemasarannya, khususnya di tingkat periklanannya

Dengan menggabungkan kedua pembagian tadi, dapat disimpulkan bahwa terdapat tiga jenis strategi dilihat dari tingkatannya, yaitu strategi di tingkat perusahaan, strategi di tingkat bisnis, dan strategi di tingkat fungsional. 


\section{B. MELAKUKAN MANAJEMEN STRATEGIS}

\section{Penyusunan Strategi}

Perusahaan melakukan strategi untuk memenangkan persaingan bisnis yang di jalankannya, serta untuk mempertahankan keberlangsungan kehidupan perusahaan dalam jangka panjang. Untuk melakukan strategi, dilakukan proses penyusunan strategi yang pada dasarnya terdiri dari tiga fase, yaitu penilaian keperluan penyusunan strategi. analisis situasi, dan pemilihan strategi.

\section{a. Penilaian Keperluan Penyusunan Strategi}

Sebelum strategi disusun, perlu ditanyakan terlebih dahulu apakah memang penyusunan strategi-baik strategi baru maupun perubahan strategi perlu untuk dilakukan ataukah tidal. Hal ini terkait dengan apakah strategi yang akan dilakukan memang sesuai dengan tuntutan perubahan di lingkungan ataukah sebaliknya, lebih baik mempertahankan strategi yang telah ada misalnya Fase untuk menilai perlu tidaknya sebuah strategi disusun akan menjadi fase yang memakan waktu cukup lama, terutama jika dikaitkan dengan persoalan inersia dalam persaingan (inertia of competition) Inersia dalam persaingan adalah suatu kondisi di mana para anggota dalam organisasi sudah merasa puas dengan keadaan yang dialami perusahaan sehingga merasa tidak perlu dalam melakukan perubahan strategi. Salah satu cara untuk menilai perlu tidaknya sebuah strategi baru adalah dengan menilai strategi yang sedang dijalankan, baik buruknya, serta hasil yang diperoleh perusahaan dengan penggunaan strategi tersebut.

\section{b. Analisis Situasi}

Pada tahap ini, perusahaan perlu melakukan analisis mengenai kekuatan dan kele mahan yang dimiliki oleh organisasi sekaligus juga menganalisis peluang dan tantangan yang dihadapi oleh organisasi. Salah satu pendekatan paling populer dalam fase ini adalah apa yang dinamakan sebagai analisis SWOT (SWOT analysis) SWOT adalah kependekan dari Strength (kekuatan), Weakness (kelemahan), Opportunities (peluang), dan Threat (tantangan). Analisis mengenai kekuatan dan kelemahan terkait dengan faktor-faktor yang telah dimiliki dan ada pada perusahaan, misalnya sumber daya manusia yang produktif (kekuatan), keterbatasan dana (kelemahan), dan lain sebagainya. Adapun analisis mengenai peluang dan tantangan terkait dengan faktor-faktor yang dihadapi oleh perusahaan dari pihak eksternal, misalnya jumlah pesaing yang bertambah (tantangan), kebutuhan akan produk yang ditawarkan perusahaan bertambah (peluang), pendapatan masyarakat yang meningkat (peluang), dan lain sebagainya.

\section{c. Pemilihan Strategi}

Setelah perusahaan melakukan analisis terhadap keadaan internal dan eksternal per usahaan, maka perusahaan perlu menentukan strategi yang akan diambil dari berbagai alternatif yang ada. Pada dasarnya alternatif strategi terbagi ke dalam tiga bagian besar, yaitu strategi yang cenderung mengambil risiko, yaitu strategi yang menyerang atau agresif (aggresive or offensive 
strategy), strategi yang cenderung menghindari risiko, yaitu strategi bertahan (defensive strategy), serta strategi yang memadukan antara mengambil risiko dan menghindari risiko Arunya, berada di tengah-tengah Strategi ini sering dinamakan sebagal turn-around strategy.

\section{Proses Manajemen Strategis}

Jika penyusunan strategi telah diketahui prinsipnya secara umum, bagaimana mana jemen strategi dilakukan? Setidaknya proses manajemen strategis dapat dibagi dua secara garis besarnya, yaitu perencanaan strategis (strategic planning) dan implementasi strategi (strategic implementation Adapun rincian dari setiap proses manajemen strategis tersebut dapat dilihat dalam Gambar 74.

\section{a. Perencanaan Strategis}

Proses ini mencakup dari mulai penentuan tujuan (sebagaimana yang telah diterang kan dalam bab mengenal perencanaan) hingga penyusunan strategi sebagaimana yang telah diuraikan pada bagian sebelumnya. Sebagai contoh untuk tujuan yang ditetapkan adalah: "menjadi pemimpin pasar (market leader) dalam bisnis seluler" Kemudian sebagai contoh untuk formulasi strategi, misalnya: "Indah Selular melakukan akuisisi terhadap perusahaan kompetitor (Permai Selular) yang lemah secara manajemen, namun memi ai keunggulan dari pangsa pasar "Strategi ini termasuk ke dalam strategi ofensif karena ia melakukan aktivitas proaktif terhadap apa yang dihadapi oleh perusahaan pesaing walaupun risikonya cukup tinggi

\section{b. Implementasi Strategi}

Proses ini mencakup implementasi yang dijalankan berdasarkan strategi yang dipilih dan juga pengendalian atas implementasi yang dilakukan Sebagai contoh pada fase administrasi yaitu dengan penggabungan dua perusahaan besar misalnya perusahaan Indah Seluler dan Permai Selules. Adapun contoh pengendalian atas strategi yang dilakukan adalah ketika misalnya berhadapan dengan persoalan bahwa, "konsumen dari Permai Seluler telah berpindah ke Makmur Seluler" Keadaan ini tidak sejalan dengan tujuan yang ingin dicapai untuk menjadi pemimpin pasar dalam bisnis seluler, dikarenakan prediksi Indah Seluler untuk meraih pangsa pasar dari Permai Seluler ternyata gagal karena konsumen Permai Seluler telah berpindah kepada pesaing lainnya Oleh karena itu, maka perlu dilakukan antisipasi dan solusi atas situasi tersebut, maka fase berikutnya adalah kembali meng evaluasi penentuan tujuan dan juga penyusunan strategi. 


\section{C.TINGKATAN TINGKATAN MANAJEMEN STRATEGIS}

Setelah kita mengetahui konsep dasar strategi dan proses manajemen strategis se bagaimana telah diuraikan di atas, maka pertanyaannya adalah strategi manakah yang harus saya pilih untuk setiap tingkatan strategi sebagaimana telah diterangkan di awal? Bagaimana strategi untuk tingkatan perusahaan (corporate level). bagaimana strategi untuk tingkatan bisnis (business level strategy), dan bagaimana strategi untuk tingkatan fungsional (functional level) Bagian berikut akan menguraikan secara ringkas mengenal hal ini.

\section{Strategi di Tingkat Korporat}

Strategi untuk tingkat perusahaan atau korporat adalah strategi yang akan dilakukan perusahaan untuk menjawab pertanyaan seperti, "Bisnis apakah yang sebaiknya dilakukan oleh perusahaan?" Strategi ini juga dilakukan dalam rangka menjawab apakah jenis bisnis yang selama ini dilakukan masih perlu dilanjutkan ataukah tidak.

Terdapat dua pendekatan dalam melakukan strategi tingkat perusahaan ini, yaitu pendekatan strategi portofolio (portfolio strategy) dan strategi utama (main strategy).

\section{a. Strategi Portofolio (Portfolio Strategy)}

Strategi portofolio adalah strategi yang dilakukan perusahaan untuk meminimalkan risiko bisnis yang dijalankannya dengan melakukan investasi di berbagai sektor bisnis. Hal ini terkait dengan ungkapan don't put your money into one basket yang kurang lebih dapat diartikan bahwa jangan melakukan investasi hanya pada satu sektor bisnis saja. Salah satu contoh praktik yang sederhana adalah ketika perusahaan membeli saham dari berbagai jenis perusahaan yang bergerak di sektor yang berbeda-beda. Strategi ini dilakukan de ngan landasan bahwa jika suatu ketika satu sektor bisnis mengalami kerugian, bisa jadi kerugian itu dapat ditutupi dari keuntungan pada sektor yang lain. Beberapa cara yang dapat dilakukan pada strategi portfolio ini adalah:

\section{- Pengambilalihan perusahaan tertentu (acquisition)}

Strategi ini dilakukan dengan jalan membeli atau mengambil alih perusahaan perusa haan lain dalam satu industri tertentu. Misalnya, perusahaan pesaing yang tujuannya adalah untuk mengurangi persaingan di sektor bisnis tersebut.

\section{- Diversifikasi yang tidak berhubungan (unrelated diversification)}

Strategi ini dilakukan dengan jalan membentuk suatu bisnis pada sektor baru atau mengambil alih perusahaan yang berbeda sektor dengan alasan untuk meraih peluang pada sektor lain dalam dunia bisnis. 


\section{- Penentuan strategi berdasarkan analisis Matriks BCG.}

Matriks BCG (BCG Matrix) adalah model analisis yang diperkenalkan oleh Boston Consulting Group untuk mengetahui bagaimana posisi perusahaan dalam sektor bisnis yang sedang dijalankannya. Apakah sebaiknya perlu dikembangkan, beralih, atau bertahan. Analisis Matriks BCG didasarkan pada indikator pertumbuhan pasar (market growth) dan pangsa pasar (market shares) dari setiap unit bisnis yang dimiliki perusahaan. Misalnya, perusahaan A yang merupakan perusahaan besar bergerak di bidang makanan, minuman, keuangan, dan juga property. Keseluruhan unit bisnis tersebut dinamakan sebagai strategic business unit (SBU) dari perusahaan A. Analisis matriks BCG dapat membantu perusahaan untuk mengetahui pada posisi seperti apa perusahaan dilihat dari keseluruhan bisnisnya berdasarkan posisi setiap unit bisnis yang dijalankannya.

1. Question mark. Pada saat perusahaan mendapatkan penilaian question mark atau tanda tanya, ini berarti bahwa dapat tidaknya perusahaan melanjutkan bisnis yang sedang dijalankan sangat bergantung, misalnya pada kondisi keuangan yang ada. Hal tersebut dikarenakan bahwa perusahaan memerlukan tambahan dana untuk mening katkan pangsa pasar di saat pertumbuhan pasar dari bisnis yang dijalankannya tinggi.

2. Star. Pada saat perusahaan mengalami kondisi dengan indikator star (bintang), ini berarti bahwa perusahaan tengah meraih kesuksesan dalam bisnisnya. Hal tersebut dikarenakan pertumbuhan pasar dalam bisnis yang dijalankan mampu diimbangi dengan kemampuan perusahaan untuk meraih pangsa pasar yang tinggi pula.

3. Cash cow. Pada saat perusahaan mengalami dengan indikator cash cow, perusahaan mengalami kesuksesan yang tinggi dengan memperoleh pendapatan yang berlebih dari pangsa pasar yang tinggi sekalipun pertumbuhan pasar relatif rendah Dalam ke adaan seperti ini, perusahaan tidak memerlukan investasi yang berlebih dalam bisnis ini. Sebaliknya, ketersediaan dana yang dimiliki oleh perusahaan dapat dialokasikan untuk kegiatan bisnis yang lain.

4. Dogs. Pada saat perusahaan mengalami kondisi dengan indikator dogs (anjing). perusahaan mengalami kondisi yang buruk dalam sektor bisnis yang dijalankannya Selain pangsa pasar yang rendah, pertumbuhan pasarnya juga rendah. Bisnis pada sektor ini sering kali disubsidi dari bisnis pada sektor lain yang mungkin dijalankan oleh perusahaan. Pada kondisi seperti ini, perusahaan sebaiknya menutup bisnis yang dijalankan.

Ringkasnya, dengan menggunakan analisis Matriks BCG, perusahaan dapat menilai keadaan setiap unit bisnis yang dijalankannya, apakah masih perlu untuk diteruskan, dikembangkan, atau justru harus ditutup. 


\section{b Strategi Utama (Main Strategy)}

Strategi utama atau main strategy adalah strategi yang dapat dipilih oleh perusahaan untuk mempertahankan kegiatan perusahaan dalam jangka panjang. Terdapat tiga jenis strategi utama, yaitu strategi pertumbuhan (growth strategy), strategi kestabilan (stability strategy), dan strategi penghematan (retrenchment strategy).

\section{Strategi di Tingkat Bisnis}

Strategi di tingkat bisnis dilakukan dalam rangka mempertahankan kemampuan kom pedisi dari perusahaan dibandingkan para pesaingnya pada bisnis yang sama. Dan untuk mengetahu! posisi perusahaan di tengah persaingan tersebut, perlu dilakukan analisis lingkungan mikro dari perusahaan tersebut yang menggambarkan posisi perusahaan, pe saing, pemasok, dan juga pelanggan yang memerlukan produk dari bisnis yang dijalankan. Salah satu model yang dapat membantu perusahaan dalam melakukan analisis ini adalah model lima faktor pendorong kompetisi dari Michael Porter-dikenal sebagai Five Forces Factor Model-yang terdiri dari faktorfaktor:

a. Pelanggan

Pelanggan adalah faktor utama mengapa sebuah bisnis dijalankan. Sehingga indicator yang dapat menunjukkan berhasil tidaknya perusahaan dalam menjalankan bisnis adalah sampai sejauh mana perusahaan dapat memperoleh pelanggan sebanyak banyaknya sekaligus loyal terhadap perusahaan kita.

b. Persaingan dalam bisnis yang sama

Faktor kedua adalah persaingan dalam bisnis yang sama, yaitu antara perusahaan dengan perusahaan pesaing yang menjalankan bisnis yang sama. Perusahaan perlu menyadari bahwa dalam lingkungan bisnis yang kompetitif tidak hanya perusahaan mereka yang bergerak dalam pemenuhan dan penyediaan barang dan jasa bagi pe langgan, tetapi juga terdapat perusahaan lain yang bertindak sebagai pessing bagi perusahaan dalam mendapatkan pelanggan.

c. Potensi pendatang baru

Tingkat pertumbuhan bisnis yang tinggi akan mengundang peru sahaan baru untuk masuk ke dalam bisnis yang sama. Oleh karena itu, perusahaan perlu mewaspadai faktor ketiga ini. Masuknya pendatang baru akan menyebabkan persaingan semakin ketat dan perusahaan harus semakin pandai dalam melakukan strategi bersaingnya agar bisa memenangkan persaingan dalam bisnis.

d. Pemasok faktor input

Salah satu faktor yang akan dapat mendorong sebuah bisnis untuk berhasil, terutama bisnis yang memerlukan faktor input adalah sampai sejauh mana perusahaan memiliki jaringan dengan pemasok yang dapat memberikan keunggulan bagi perusahaan, 
terutama jika pemasok dapat memberikan faktor input dengan harga yang lebih murah.

e. Perusahaan substitusi

Faktor kelima atau faktor terakhir dari modelnya Porter adalah perusahaan substitusi. Perusahaan perlu menyadari bahwa jika kondisi bisnis berubah, maka pelanggan da pat beralih ke perusahaan substitusi.

Terdapat berbagai strategi yang bisa dilakukan, di antaranya adalah strategi pemosisian (positioning strategi) dan strategi penyesuaian (adaptive strategy)

a. Strategi Pemasisian (Positioning Strategy)

Strategi pemilian atau positioning strategy dapat dilakukan oleh perusahaan untuk memastikan dengan cara bagaimana perusahaan dapat memperoleh perhatian dari pelang gan atau memenangkan persaingan. Menurut Porter, ada tiga jenis atrategi umum (gemeric strategy yang dapat dilakukan, yaitu strateg keunggulan birya irunt leadership strategy. strategi diferenstast differentiation strategy, dan strategi fokus (business focus strategy).

b. Strategi Penyesuaian (Adaptive Strategy)

Strategi penyesuaian atau adaptive strategy dilakukan perusahaan dengan tujuan untuk memilih strategi yang paling sesuai ketika perusahaan berhadapan dengan berba gai perubahan yang terjadi di lingkungan bisnis yang sedang dijalankan. Terdapat empat jenis strategi penyesuaian, yaitu strategi defenders, strategi prospectors, strategi analyzers, dan strategi reactors.

\section{Strategi di Tingkat Fungsional}

Strategi di tingkat fungsional sering kali dinamakan sebagai strategi langsung atau direct strategy Hal ini disebabkan perusahaan cenderung melakukan persaingan pada jenis bisnis tertentu yang sedang dijalankan, dan tidak pada tingkat perusahaan maupun sektor bisnis yang diperdagangkan. Sebagai contoh adalah persaingan antara sampo Pantene de agan sampo Sunsilk. Perusahaan bersaing langsung pada tingkat produk sampo tersebut, dan tidak terlalu tampak mereka bersaing pada tingkat yang lebih tinggi, misalnya pada tingkat bisnis peralatan mandi maupun pada tingkat perusahaan antara PT Unilever dan PT P\&G walaupun pada kenyataannya dampak dari persaingan langsung tersebut akan memengaruhi pula kinerja persaingan di tingkat bisnis dan tingkat perusahaan.

Terdapat dua faktor yang menentukan bagaimana strategi di tingkat fungsional perlu dilakukan. Kedua faktor tersebut adalah kesamaan pasar dan kesamaan sumber. 


\section{a. Kesamaan pasar}

Kesamaan pasar terkait dengan tingkat persaingan yang sama antara kedua perusaha an dalam hal meraih pelanggan melalui jenis produk yang ditawarkannya. Misalnya untuk kasus sampo Pantene dan Sunsilk. Kedua produk ini sama-sama bersaing untuk memperoleh pelanggan yang dapat diperkirakan sama, yaitu kaum wanita, remaja, dan mungkin sebagian ibu-ibu. Akibatnya, kedua perusahaan akan bersaing secara ketat dalam rangka memperoleh pelanggan melalui berbagai cara yang mungkin dapat dilakukan oleh perusahaan, apakah dari segi efisiensi biaya, agresivitas dalam periklanan, dan lain sebagainya.

b. Kesamaan sumber

Kesamaan sumber terkait dengan keadaan persaingan di mana perusahaan memiliki kesamaan dalam faktor mana mereka bersaing. Misalnya, untuk kasus persaingan sam po di atas, kedua produk tersebut sama-sama memiliki sumber persaingan yang sama, yaitu misalnya pada bauran periklanannya. Oleh karena itu, kedua perusahaan saling bersaing melalui media periklanan yang tersedia di masyarakat Kita dapat melihat bagaimana kedua perusahaan mengeluarkan berbagai jenis dan bentuk periklanan yang berubah-ubah untuk periode waktu yang relatif singkat. Misalnya, dari mulai mempromosikan rambut yang hitam, rambut yang sehat melalui pemeriksaan alat tertentu, hingga rambut yang lurus dan lembut. Jika perusahaan bisa mengetahui dari faktor mana perusahaan pesaing melakukan sumber persaingannya, maka perusahaan akan melakukan reaksi yang sama berdasarkan apa yang dilakukan pesaingnya.

Strategi di ingkat fungsional sering kali dikenal sebagai strategi aksi dan reaksi Dalam teori mikro, konsep persaingan ini akan lebih mudah dipahami ketika kondisi persaingan di pasar memiliki bentuk struktur pasar yang oligopolis, di mana jumlah perusahaan dan pesaingnya di suatu bisnis relatif sedikit. Akibat jumlah perusahaan pada suatu bisnis se dikit, maka aksi dan reaksi dari persaingan antarperusahaan akan sangat tampak agresil dan saling membalas satu sama lainnya. 


\section{BAB III}

\section{PENUTUP}

\section{A. Kesimpulan}

Strategi adalah rencana yang menyeluruh dalam rangka pencapaian tujuan organisasi. Bagi perusahaan, strategi diperlukan tidak hanya untuk memperoleh profit, tetapi juga untuk mempertahankan kelangsungan hidup perusahaan di masa yang akan dating. Terdapat tiga komponen dalam strategi, yaitu kompetensi yang berbeda, ruang lingkup, dan distribusi sumber daya yang dimiliki oleh perusahaan. Ketiga komponen tersebut menjadi bahan pertimbangan akan bagaimana strategi dilakukan oleh perusahaan. Manajemen strategis pada dasarnya adalah proses bagaimana strategi disusun dan diimplementasikan. Oleh karena itu, proses manajemen strategis terbagi dua, yaitu perencanaan strategis yang terdiri dari penentuan tujuan dan penyusunan strategi, dan implementasi strategi yang terdiri dari pelaksanaan strategi dan pengendalian dari implementasi strategi yang dijalankan. Pada praktiknya, jenis strategi yang dilakukan berbeda berdasarkan tingkatannya, yaitu strategi pada tingkat perusahaan, strategi pada tingkat bisnis, dan strategi pada Strategi pada tingkat perusahaan pada dasarnya dilakukan untuk menjawab dalam sektor apa sebaiknya perusahaan berbisnis. Strategi pada tingkat bisnis pada dasarnya dilakukan untuk menjawab pertanyaan yang terkait dengan bagaimana posisi bisnis yang dijalankan dibandingkan dengan pesaing yang ada di pasar. Strategi pada ting kat fungsional dilakukan untuk menjawab apa saja yang perlu dilakukan perusahaan untuk memenangkan persaingan. 


\section{DAFTAR PUSTAKA}

Ernie Tisnawati Sule dan Kurniawan Saefullah.2005.Pengantar Manajemen. jakarta:Indonesia Prenadamedia Group. 